\title{
Antoine Compagnon, Le Cas Bernard Fä̈, du Collège de France à l'indignité nationale
}

\section{Mireille Brangé}

\section{(2) OpenEdition}

1 Journals

\section{Édition électronique}

URL : http://journals.openedition.org/studifrancesi/7020

DOI : ERREUR PDO dans /localdata/www-bin/Core/Core/Db/Db.class.php L.34 : SQLSTATE[HY000]

[2006] MySQL server has gone away

ISSN : 2427-5856

\section{Éditeur}

Rosenberg \& Sellier

Édition imprimée

Date de publication : 1 septembre 2010

Pagination : 404

ISSN : 0039-2944

\section{Référence électronique}

Mireille Brangé, «Antoine Compagnon, Le Cas Bernard Faÿ, du Collège de France à l'indignité nationale », Studi Francesi [En ligne], 161 (LIV | II) | 2010, mis en ligne le 30 novembre 2015, consulté le 07 janvier 2021. URL : http://journals.openedition.org/studifrancesi/7020 ; DOI : https://doi.org/10.4000/ studifrancesi.7020

Ce document a été généré automatiquement le 7 janvier 2021.

\section{(c) (i) $\odot$}

Studi Francesi è distribuita con Licenza Creative Commons Attribuzione - Non commerciale - Non opere derivate 4.0 Internazionale. 


\title{
Antoine Compagnon, Le Cas Bernard Faÿ, du Collège de France à l'indignité nationale
}

\author{
Mireille Brangé
}

\section{RÉFÉRENCE}

ANTOINE COMPAGNON, Le Cas Bernard Faÿ, du Collège de France à l'indignité nationale, Paris, Gallimard, 2009, pp. 209.

1 Après ses études sur Brunetière et sur les antimodernes, l'A. enquête sur le «cas» B. Faÿ (1893-1978), parfait jeune proustien issu d'une famille ultra-catholique, ami de Cocteau, de Gide, du Groupe des Six, et «ce dont nous imaginons tous qu'un Français a l'air» selon B. Imbs. Comparatiste spécialiste des USA, il y parraina les premières études sur Proust et obtint la première chaire consacrée aux États-Unis au Collège de France. Nommé administrateur de la Bibliothèque Nationale en 1940, il fut condamné à la Libération pour intelligence avec l'ennemi. En damnatio memoriae, ses portraits disparurent de ces institutions et on rendit compte de ses livres sans le nommer.

2 C'est à cette figure gommée et à cette «énigme» pour lui entière (p. 12) que s'attache Antoine Compagnon. Comment passe-t-on «du Bœuf sur le toit à la Révolution Nationale» (p. 10)? Comment un américanophile devient-il hostile à la démocratie libérale? Comment un spécialiste de la franc-maçonnerie contribue-t-il à son interdiction? Comment voue-t-il son érudition subtile et son goût des archives à la persécution, à la délation et à la propagande antimaçonniques? Comment le minoritaire, homosexuel et boiteux, se mue-t-il en inquisiteur? Comment l'intellectuel s'enferre-t-il dans l'erreur après Guerre?

Dans ce portrait cubiste, l'A. multiplie les pistes. De quoi Bernard Faÿ est-il le nom? Ni d'une fascination gay pour le fascisme (il est antilibéral influencé par C. Schmitt), ni d'un antisémitisme chrétien (la fixation de cet ami et protecteur de Gertrude Stein est 
anti-maçonne), ni seulement d'un arrivisme revanchard. Selon l'A., Bernard Faÿ est aussi «un enfant tout absorbé par la dégustation de friandises au milieu de la tourmente» (p. 195) et un esprit brillant dont l'ouverture intellectuelle se réduit en même temps que s'efface le "Gay Paree», perdant toute nuance dans sa haine des responsables supposés de la dissolution de la civilisation catholique et monarchique française. Il se croit une «droiture au prix de la solitude» (p. 120). L'A. suggère un naufrage amer et sans grandeur.

4 Le «cas» est aussi celui d'une troublante biographie. L'A. avoue les proximités (Proust, le Collège de France, l'américanophilie, le goût de l'art moderne) qui l'ont conduit à s'intéresser à cette figure de «la trahison de soi-même», du «reniement de sa jeunesse», du «désaveu de la collégialité», du «renoncement à l'amitié», lui, issu de la génération de la Libération, hantée par la «question existentielle insoluble»de son propre comportement éventuel (p. 7) et découvrant la longue persistance des idées et des cercles vichystes. Tout en (se) persuadant de l'intérêt de cet «itinéraire à la fois ordinaire et très singulier de transfuge de la modernité», il concède qu'il «aurait peutêtre mieux valu ne pas ouvrir son placard» (p. 196) et cette réticence contamine tout, aveu à mi-mots que l'homme «inexpliquable et inexpiable» (p. 191) auquel il a consacré un livre n'était pas son genre. 